\title{
Legal Qualification
}

\section{as a Logical Method of Cognition}

\author{
Valerii N. Vlasenko* \\ Russian Academy of Justice \\ 69 Novocheremushkinskaya Str., Moscow, 117418, Russia
}

Received 04.11.2015, received in revised form 10.12.2015, accepted 28.12.2015

\begin{abstract}
The article examines in detail the logic basis of legal qualification, the major stage of application of the law, the means of specification of the provisions of the rule of law. Two blocks of logic rules to be observed in the course of legal qualification are analyzed: the organic laws of logic (identity, noncontradiction, the excluded middle, sufficient reason) and the rules of construction of categorical syllogisms. The author affirms that careful research of logic forms of legal qualification used in the course of application of the law, will promote development and implementation of logical programmes (algorithms) of qualification in the work of law enforcement authorities, first of all, for "typical cases" and, hence, will lead to automation of this process, realization of "The Electronic Judge" programme, which has already been introduced in some countries, mainly Latin and Central America.
\end{abstract}

Keywords: law enforcement, law (legal) qualification, logic basis of legal qualification, legal uncertainty, logical mode in the basis of qualification, algorithm of qualification, perfection of the decision-making process, efficiency and promptness in justice, logical nature of law.

DOI: 10.17516/1997-1370-2016-9-1-210-217.

Research area: law.

In the general theory of law, legal qualification is considered as an intellectual activity with determination of conformity or nonconformity of the features of the actual real circumstances with the features of the legal fact abstractly outlined by the rule of law, as well as the result of this process ${ }^{1}$. Legal qualification is an independent and critical stage of law enforcement and, of course, the condition that ensures the quality of implementation of legal regulations in practical life.

The main objective of legal qualification is to determine the legal nature of a specific factual circumstance, i.e. whether the occurrence of legal consequences is connected herewith. Analyzing the origin and destination of the actual circumstance, the law enforcer "considers the actions and behaviour of people using the rule of law" 2 and "defines a fact of reality as a legal phenomenon, which the subject of law should treat according to its nature"3. In other words, legal qualification is a means of transition from the situation of legal uncertainty in evaluation of certain factual circumstances to the situation of legal certainty expressed in the specification of the provisions of law and setting the legal

(c) Siberian Federal University. All rights reserved

* Corresponding author E-mail address: vlasenko84@rambler.ru 
significance of these facts ${ }^{4}$. Fairness, efficiency and validity of the final decision as a result of qualification depends on the quality determining the legal nature of the factual circumstances, on the ability of the law enforcer to follow certain regulations of qualification ${ }^{5}$ (including logical), and, eventually, on the level of legal knowledge of the law enforcer, including their ideas about the nature and purpose of law, the ability to identify what is legally significant in a specific act.

Legal literature devoted both to the general theory of law $^{6}$ and its application in certain fields ${ }^{7}$, has covered the legal aspects of legal qualification and its place in the law enforcement process quite thoroughly.

However, legal qualification can be determined not only as a legal phenomenon, but as a logical method of cognition used by the subject of law enforcement. The latter is expressed in both following the organic laws of logic in the course of evaluation of the factual circumstances (identity, non-contradiction, excluded middle, sufficient reason), and the rules of construction of logical syllogisms.

We cannot but agree with the view that it is extremely difficult to find another field of public life where violation of the laws of logic, coming to wrong conclusions, giving false arguments could cause such significant harm as in the field of law ${ }^{8}$. Logical reasoning, strict adherence to the laws of thought are the basic and essential requirements for each lawyer. In fair opinion of N.V. Mikhalkin, knowledge of logic is an essential element of a common spiritual culture of the judges ${ }^{9}$. The legitimacy, effectiveness and efficiency of justice depend largely on the ability of judges to come to conclusions, examine evidence and make decisions. Therefore, knowledge of the basic rules and laws of logic in law enforcement can reduce the number of errors, among which, as practice shows, there is a significant proportion of logical errors. ${ }^{10}$.
The logical process of legal qualification is defined as a set of "cognitive techniques subordinate to the laws of logical thinking" and is a reflection of factual evidence existing in reality (deeds, processes, objects, phenomena) and legal realities, as well as their ratio in the mind of the law enforcer ${ }^{12}$. Schematically, the structure of the "logical thought" of the qualification process, the logical framework of the ruling state power withdrawal of the competent body is nothing but the conclusion (categorical syllogism), in which the role of the major premise is played by the specific regulatory requirement and the minor premise is a specific legal fact as the object of knowledge of the law enforcer. "The most elementary, primary cell of the law existence aimed at resolving situations (cases) in the practical life of people is already a logical syllogism in which the major premise is a legal norm (formally constituted or subjectively represented), and the minor premise is the given case, the conclusion is the authoritative, legally significant decision"13.

The types of the syllogism, which differ from each other by their qualitative and quantitative characteristics of premises and conclusions, are called the modes of the syllogism ${ }^{14}$. Aristotle determined 19 out of 64 modes to be valid (apodictic, i.e. allowing to necessarily conclude about the only possible relationship between the subject and the predicate ${ }^{15}$ ), which are divided into 4 figures. The ability to distinguish between the figures of the syllogism is of practical importance, since each figure shows different methods of handling the premises. Therefore, if one has to prove the "validity" of a single or individual judgment, the first figure of the syllogism is used when a single case is considered in terms of the general rule, if one has to deny a single affirmative judgment, it is necessary to use the second figure syllogism, etc. ${ }^{16}$ The modes of syllogisms are distributed by the figures as follows: 
Figure 1 - AAA (Barbara), EAE (Celarent), AII (Darii). EIO (Ferio).

Figure 2 - EAE (Cesare), AEE (Cesaro), EIO (Camestres), AOO (Festino).

Figure 3 -IAI (Disamis), AII (Datisi), OAO (Bocardo), EIO (Ferison).

Figure 4 - AEE (Camenes), IAI (Dimaris), EIO (Fresison) ${ }^{17}$.

Not all modes of reasoning are widely used in practice, though this does not mean that they only appear in logic textbooks and are not applied in the practice of thinking. The fact that we are not able to immediately take advantage of them in practice, does not imply that they should be excluded from the system of sciences. It is possible that the development of new needs of thinking and scientific knowledge will require such a plan of modes of reasoning. It is beyond argument that a deep knowledge of figures and modes of the human thought will be required due to the development of automated systems, the expansion of the practice of machine translation, etc. Creating even the simplest automated system capable of producing some elementary logical operations is impossible without a thorough knowledge of the principles and rules of the syllogism.

In the course of syllogistic reasoning during mental activity, one should observe a number of logical rules arising from the action of the organic laws of logic (identity, non-contradiction, sufficient reason and the excluded middle) in order to come to a valid conclusion. Application of the laws of logic can detect invalid arguments about legal circumstances and contribute to the proper qualification, respectively, non-compliance with the laws of logic leads to logical errors.

Therefore, which figures and modes can be applied and are really used during legal qualification?

In order to answer this question, we should take into account the logical rules for each figure of syllogisms, which are the criteria for valid reasoning adapted specifically for this figure. If at least one of the rules is violated, the conclusion made using these figures would be wrong; if nothing necessarily comes from the premises of a syllogism, there is no syllogism ${ }^{18}$. The categorical reasoning, in fact, secures the conclusions that were obtained during the preliminary discussion in the form of conditional-categorical and dividing-categorical conclusions. Herewith, it is necessary to take into account their relationship, the nature of the modes (positive or negative) used in the preliminary stages of qualification. The fact is that the affirmative mode of preliminary qualification (on the compliance of the features of actual circumstances with the features set by the rule of law) should conform to the modes of the first figure of general qualification, mainly Barbara mode, and the negative mode to the modes of the second figure, mainly Camestres mode.

Thus, with the help of the first mode of the first figure particular conclusions come from the general provisions. This is the most typical form of deductive reasoning. The total abstract statement (for example, the rule of law) is analyzed to make conclusions regarding a particular phenomenon, the fact of reality. For the first figure conclusions, the minor premise should be affirmative, and the major premise should be universal: for example, the attack for the purpose of thievery, committed with violence dangerous for life or health, is robbery (Article 162 of the Criminal Code of the Russian Federation); Mr. K. applying violence dangerous for life, attacked Mr. P. in order to steal his/her property, therefore, the act of $\mathrm{K}$. is robbery.

The first mode of the second figure is used to refute the affirmative judgment, especially when it is necessary to show that a separate case or feature cannot be subsumed under the universal statement. Therefore, one of the premises should 
be negative, and the major premise should be universal: illegal banking activity is punishable, this banking operation is not punishable, this banking operation is not illegal banking activity.

The modes of the third figure are used to refute universal statements: the minor premise should be affirmative and the conclusion should be particular. This kind of syllogisms are, in the first place, Disamis and Felapton. These modes are used in the implementation of normative control when the regulatory direction of minor legal force, is checked for compliance with the act of major legal force.

The fourth figure does not give universal affirmative conclusions, the minor premise should be universal, that is why this figure is rather artificial and is not applied for the purpose of legal qualification.

It should be noted that simple syllogisms are rarely used in the practice of the mental activity of law enforcers (which is usually due to the complexity in determining the nature of the legal relationship or, conversely, due to their evident assessment, which leads to a reduced type of the syllogism, as well as due to the fact that the major premise if not only the rule of law, but several systemically interconnected substantive and procedural norms). Therefore, much more often the qualifying syllogism becomes more complex, while it consists of a chain of simple syllogisms, namely in the form of:

a) polysyllogism, i.e. a combination of several syllogisms with each other in such a way that the conclusion of one of them becomes the premise for another one. For example, let us consider the following conclusion: "Appropriation or embezzlement is the theft of property of another entrusted to the guilty. Mr. P. stole the property of another. The property was entrusted to him. Therefore, the actions of Mr. P have all the features of appropriation. Appropriation is subject to Article 160 of the Criminal Code of the Russian Federation. Therefore, the actions fall under Article 160 of the Criminal Code of the Russian Federation".

b) sorite, i.e. a chain of reduced syllogisms, in which either major or minor premise is omitted while they are obvious for the qualification of the subject. In case of the previous example of polysyllogisms in the mental activity of experienced law enforcers, the chain would be commonly reduced as follows: "Mr. P. stole the property of another entrusted to him. Therefore, his actions fall under Article 160 of the Criminal Code of the Russian Federation".

c) enthymeme, i.e. an argument, which does not contain neither major nor minor premises, while they are implied because they express a well-known statement, which does not require any establishment or proof. Consequently, there are two types of enthymemes may be two kinds:

- in the first case, there is no major premise. This scheme is applied for the qualification of the cases of special proceedings (in accordance with the subsection IV of the Code of Civil Procedure of the Russian Federation, Chapter 27 of the Code of Arbitration Procedure). A distinctive feature of special proceedings is the lack of dispute about the law. A judge has to determine a particular fact, notwithstanding whether it took place or not (for example, establishment of the fact of acknowledgement of paternity, acceptance of inheritance, adoption, the fact of possession and use of real estate by the entity as its own, etc.), and to qualify it as legally significant, or insignificant;

- in the second case, the conclusion does not contain the minor premise while it is well-known or has a prejudicial effect.

To make a valid conclusion from the premises (law enforcement decision), it is necessary to exactly establish both premises. The 
peculiarity of judicial reasoning is that the major premise (rule of law) is not the subject to proof. "If the rule of law is set positively, it means that it has a positive value for the judge" ${ }^{19}$. During the study of the major premises, the hypothesis of the norm has a crucial meaning, establishing a circle of life circumstances, the presence or absence of which is the basis for the application of this law. Herewith, the major premise as the basis for legal qualification should be comprehensively and systematically interpreted and should be reasonable. This applies to all cases of law enforcement. Even when the qualification is simple and obvious, and the establishment of the applicable rule is easy due to the current practice in this category of cases. In such cases, it means that the interpretation of this law has been already established and there is no doubt in it, its result is presumed.

The minor premise contains the facts established during the case. They should fully or partially coincide with the system of factual circumstances set in the hypothesis of the norm. It is the coincidence of the set conditions and real ones that underlies the conclusion of the law enforcer that the real-life circumstances are able to produce the effects provided for by the disposition and the sanction of the rule of law. Logically, decision-making is arranged from the major premise to the minor one, and then to the conclusion. It is noteworthy that logical constructions are not in one line with real actions and the progress of the law enforcer's thought, they constitute the internal logic of qualification.

At the same time, the value of the logical forms of qualification is not absolute. For proper evaluation of the facts, to observe these laws in the process of reasoning is not enough. Success, efficiency and promptness of the qualification process largely depend on the efficient and reliable determination of the original data the assessment is based on, on understanding of the law and its rules by the law enforcer, as well as knowledge and observance of the rules of legal qualification.

Indeed, it is hardly correct to reduce the application of law, making a decision only on the formal-logical operation. Any form contains content, essence of law enforcement (competent-authoritive activities on resolution of specific legal cases) as its logical part. In the process of qualifying, the law enforcer often faces ambiguous factual situations. In order to resolve them, certain law enforcement actions are required. In particular, it is understanding of the legal norm and explaining it to others, i.e. interpreting the content and grounds for the implementation of the legal norm, finding of legal norms that come into conflict with the interpreted legal rule, gaps, etc. Such situations require that the law enforcer overcomes the conflicts and gaps in legal norms. Moreover, let us note that legal norms are ambiguous: they are relatively certain, discretionary, optional or alternative legal rules that require implementation with consideration of factual circumstances of each particular dispute.

Thelawenforcerfaces complex problems with various possible solutions to the problem, which may not be correctly resolved by the knowledge of factual circumstances and corresponding rules of law alone (i.e. understanding of the law from the positivism standpoint prevailing in the domestic legal doctrine). Let us emphasize that this is most real in the cases of identification of gaps in the current legislation, in situations that require resolution of the case taking into account the discretion of the law enforcer, as well as the cases related to the assessment of non-pecuniary damage, etc. Meanwhile, the discretion of the law enforcer used in these cases should be an exception and performed strictly within the framework of the law, but in general the major premise in the process of legal qualification should be based on regulatory legal instructions. 
However, practice shows that judges resolve many of the issues arising during legal qualification by referring to the provisions developed by higher courts. Thus, reasoning of court decisions is abundant with references to the legal position of the Constitutional Court, Supreme Court and the Supreme Arbitration Court of the Russian Federation, as well as to other courts that appear to be almost a normative premise of qualification, directly substituting regulatory legal instructions. This situation is alarming. We cannot but agree with the following statement: "The analysis of judgments, for example, in the arbitration proceedings allows to conclude that the in the reasoning of the judge's decision there only one reference to the applicable law, and three or four times - to the variety of legal positions of courts ... The intensive use of legal positions in the judiciary practice leads to uncertainty of the judgment, their weakness and vagueness that could undermine the foundations of the rule of law". 20

Therefore, we have a situation when the legal nature of the factual circumstances is determined not on the basis of the rule of law, but rather taking into account the legal position of higher courts, and established judicial legal positions (practice), and thus, judicial legal positions receive the status of legal norms and legal understanding of the subject applying the law becomes sociological, which is inherent in the Anglo-Saxon legal system. This situation can not influence the process of legal qualification and its result.

Careful consideration of the issues of the logical side of legal qualification, investigation of the modes used in the process of law enforcement will contribute, in our opinion, to the development and use of logic programmes (algorithms) of qualification in law enforcement activities and, consequently, to automation of this process. This will allow law enforcers, first of all, to have a clear understanding of the sequence of actions to be undertaken for the only valid conclusion on the case, and will minimize the use of subjective assessments and ensure effective decisionmaking. The use of such software will not replace ordinary judges, and it is not what we are talking about it. Such software will only make their work more effective, especially when the case is not connected with the interpretation of provisions of the law, but with the "pure logic" when "yes" or "no" answers are required (whether the features of law violation comply with all the features of law violation provided for by the rule of law or not). It should be noted that in some countries these technologies are already applied in the course of implementation, although in an experimental mode, of the programmes "The Electronic Judge", "Justice-on-Wheels"21.

The Chinese province of Shandong has advanced even further in this respect, while electronic systems there are used in criminal proceedings, even for such serious crimes as murder, robbery, rape, infringement of public safety. All offenses were preliminarily systematized and divided into one hundred categories. Specific data are entered into the theory of the case and the system passes the sentence. The judge, of course, has the right to disagree with the decision and change it. From 2006 to 2009 , more than 2,000 criminal cases had been considered with the help of this system.

In our country, taking into account the need to achieve the main strategic goal of national information policy of "transition to the information society and entry into the global information society", in recent years much attention is paid to the use of information technologies in the field of justice, other law enforcement activities, as well as its technical support.

The supreme courts and many bodies of the executive government have adopted the concepts of informatization involving the integrated use of new information technologies, including the 
means of video conferencing, Internet technology, the technology of electronic records management, processing and storage of large amounts of data, reference data marts and boards for the display of information on the appointment of hearings on cases, automated record-keeping subsystem of the Supreme Court and other computer technologies. Often, the use of these technologies includes the concept of "e-justice". It seems that these information technologies are more related to ensuring the principle of openness and access to justice, with the technical and material support of decision-making, and not justice itself. We believe that the "e-justice" programme, in the first place, should include the problem of development and support of computer qualifying programms for law enforcement.

Therefore, we can conclude that legal qualification is a complex process of cognition and the result of this cognition, the success of which particularly depends on the knowledge and respect for the laws of logic. The issue of the logical basis of legal qualification should be investigated further.

Alekseev S.S. Obshchaia teoriia prava [General Theory of Law]. Moscow. TK Velbi, Prospekt Publishing house, 2008, $545 \mathrm{p}$.

Cherdantsev A.F. Teoriia gosudarstva i prava [Theory of State and Law]. Moscow: Iurait-M, 2002. 255 p.

Chvialeva E.V. Rol' iuridicheskoi kvalifikatsii v mekhanizme pravovogo regulirovaniia [The Role of Legal Qualification in the Mechanism of Legal Regulation]. XXVII s'ezd KPSS i razvitie teorii gosudarstva i prava [The $27^{\text {th }}$ Meeting of the CPSU and Development of the Theory of State and Law]. Interuniversity collection of research works. Sverdlovsk, 1987. P.67 etc.

2 Syrykh V.M. Materialisticheskaia teoriia prava [Materialistic Theory of Law]. Selected works. Moscow: RAP, 2011. p. 125.

Permiakov Iu.E. Pravovye suzhdeniia [Legal Judgments]: Samara, Samara Academy of the Humanities, 2005, p. 76.

4 Read more about the nature of legal uncertainty: Vlasenko N.A. Neopredelennost'v prave: poniatie I puti issledovaniia [The Uncertainty in Law: the Concept and the Way of Research]. Rossiiskoe pravosudie [Russian Justice], 2006, No. 7. pp. 4-12.

5 Rules of qualification are the techniques and methods of law enforcement with respect to the specific factual circumstance given in the relevant regulatory legal acts, as well as the techniques, developed by judicial prectice and doctrine. See Gaukhman L.D. Kvalifikatsiia prestuplenii: zakon, teoriia, praktika [Qualification of Crime: Law, Theory and Practice]. Moscow: Joint Stock Company Tsentr IurInfoR. 2003. p.9

6 Voplenko N.N., Lazarev V.M. Pravoprimenitel'naia kvalifikatsiia I iuridicheskaia spravedlivost' [Law Enforcement Qualification and Legal Justice]. Problemy deistviia prava v novykh istoricheskikh usloviiakh [Issues of the Force of Law in New Historical Conditions]. Trudy Akademii [Academy's Works]. Moscow, 1993; Diuriagin I.Ia. Primenenie norm sovetskogo prava [The Enforcement of the Soviet Law]. Sverdlovsk. Sredne-ural'skoe knizhnoe izdatel'stvo, 1973; Ershov V.V. Sudebnoe pravoprimenenie [Judicial Law Enforcement], Moscow, 1991; Kartashov V.N. Primenenie prava [Law Enforcement]. Yaroslavl: Yaroslavl University Press, 1980; Nedbailo P.E. Primenenie sovetskikh pravovykh norm [The Enforcement of the Soviet Law]. Moscow: Gosiurizdat, 1960; Pigolkin A.S. Izuchenie fakticheskih dannyh i obstoiatel'stv dela pri primenenii norm prava [The study of Actual Data and Curcamstances of the Case in Law Enforcement]. Sovetskoe gosudarstvo i pravo [Soviet State and Law], 1968, No.9; Cherdantsev A.F. Tolkovanie prava i dogovora [The Interpretation of Law and the Agreement]. Moscow: IUNITI-DANA, 2003 et al.

7 For qualification of crime see: Kudriavtsev V.N. Obshchaia teoriia kvalifikatsii prestuplenii [General Theory of Crime Qualification]. Moscow: Iurist, 1972 (1999); Naumov A.V., Novichenko A.S. Zakony logiki i kvalifikatsiia prestuplenii [The Laws of Logic and Crime Qualification]. Moscow. Iurid. Lit., 1978; Kurinov B.A. Nauchnye osnovy kvalifikatsii prestuplenii [Scientific Basis for Crime Qualification]. Moscow: Moscow University Press, 1984; Tolkachenko A.A. Teoreticheskie osnovy kvalifikatsii prestuplenii [Theoretical Basis of Crime Qualification]. Moscow: IUNITI-DANA, 2004; Kuznetsova N.F. Problemy kvalifikatsii prestuplenii [The Issues of Crime Qualification]. Moscow: Gorodets, 2007 et al. Regarding qualification of different types of agreements see: Tsyganov V., Emel'ianov A. Grazhdansko-pravovaia kvalifikatsiia pri registratsii prav na nedvizhimost' [Civil Qualification at Registration of Rights to Real Estate]. Rossiiskaia uistitsiia [Russian Justice]. 2001. No. 8; Servestnik A.A. Kvalifikatsiia dogovorov v otnosheniiakh s predprenimateliami [Agreements Qualification in Relations with Entrepreneurs]. Aktual'nye problemy pravovedeniia [Topical Issues of Legal Studies] Samara, 2003.

8 Kudriavtsev V.N. Obshchaia teoriia kvalifikatsii prestuplenii [General Theory of Crime Qualification]. Moscow: Iurist, 1972 (1999)

9 Mikhalkin N.V. Logika i argumentatsiia v sudebnoi praktike [Logic and Argumentation in Judicial Practice]. Saint-Petersburg: Piter, 2004, p. 19.

10 For more detail see: Kazgerieva E.V. Logicheskie oshibki v sudebnom pravoprimenenii [Logic Errors in Judicial Law Enforcement]. Author's abstract for the Ph.D. in Law. Moscow, 2006.

11 Andreev I. Ustanovlenie priznakov prestupleniia [Determining the Features of the Crime]. Warsaw, 1968, p. 23. 
12 For more information regarding the logical form of qualification see: Vilianskii S.I. Znachenie logiki v primenenii pravovykh form [Meaning of Logic in Application of Law Forms]. Kharkov: Kharkov Law Institute Press, 1948; Starchenko A.A. Logika v sudebnom issledovannii [Logic in Judicial Investigation]. Moscow: Gosiurizdat, 1958; Naumov A.V., Novchenko A.S. Zakony logiki i kvalifikatsiia prestuplenii [Laws of Logic and Crime Qualification], Moscow: Iurid. Lit., 1978; Kornakova S.V. Znachenie sobliudeniia zakonov logiki v protsesse kvalifikatsii prestupleniia [The Importance of Following the Laws of Logic in the Process of Crime Qualification]. Ugolovno-pravovye i kriminologichekie problem bor'by s prestupnost'iu [Criminal Matters of Law in Crime Prevention]. Collection of Works. Irkutsk: Izd-vo BGUEP, 2007. Issue 4, Part 1; Gaidamakin A.A. Polemicheskie zametki o logike prava i pravosoznanii [Polemic Notes on the Logic of Law and Legal Consciousness]. Gosudarstvo i pravo [State and Law], 2007, No. 7, pp. 92-95, et al.

13 Alekseev S.S. Voskhozhdenie k pravu. Poiski i resheniia [The Ascent to Law. Search and Solutions]. Moscow: Norma Publishing House, 2001. p. 15.

14 Getmanova A.D. Logika dlia iuristov [Logic for Lawyers]. Moscow, 2008. p. 209.

15 Let us note that S.N. Egorov reasonably proves the existence of only 16 such modes. He also notes that only 6 of them take place in the course of thinking. See Egorov S.N. Sillogizm [Syllogism]. Saint-Petersburg, 2007, pp.7-9.

16 For more information see: Kondakov N.I. Logicheskii slovar'-spravochnik [Logical Reference Dictionary]. Moscow, 1976. p.639.

17 In logic, the modes are written down by capital letters, which determine universal affirmatives, universal negatives, particular affirmatives and particular negatives. At the same time, each valid mode has a name, in which vowels determine the quality and the quantity of the premises and the conclusion.

18 Egorov S.N. Sillogizm [Syllogism]. Saint-Petersburg, 2007, p.11.

19 Mill J.S. Sistema logiki [A System of Logic]. Translated to Russian by V.N. Ivanovskii, Knizhnoe delo, 1900, P. 763

20 Vlasenko N.A. Pravovaia priroda, vidy i poniatie pravovykh pozitsii [Legal Nature, Types and Understanding of Legal Positions]. Rossiiskoe prevosudie [Russian Justice], 2008, No. 9. P. 41

${ }_{21}$ See: Brazilian Justice: Artificial Intelligence Delivers Judgment. Available at: //http://www.lenta.ru/internet/2000/04/27/ e-judge/. Such electronic systems are also actively introduced into the judicial systems of the USA, Australia and some other countries.

\title{
Юридическая квалификация
}

\section{как логический прием познания}

\author{
В.Н. Власенко \\ Российский государственный университет правосудия \\ Россия, 117418, Москва, ул. Новочеремушкинская, 69
}

В статье исследованию подлежат логические основания юридической квалификации важнейшей стадии правоприменения, средства конкретизации положений норм права. Анализируются два блока логических правил, которые необходимо соблюдать в проиессе правовой квалификации: основные законыл логики (тождества, непротиворечия, исключенного третьего, достаточного основания) и правила построения категорических силлогизмов в соответствии с его модусом. Утверждается, что тщательное исследование логических форм правовой квалификаиии, модусов, используемых в проиессе правоприменения, будет способствовать созданию и использованию в деятельности правоприменительных органов логических программ (алгоритмов) квалификачии, в первую очередь, по «типовым делам» u, следовательно, к автоматизации этого процесса, реализации программы «Электронный судья», которая уже получила свое применение в зарубежных странах, прежде всего в Латинской и Центральной Америке.

Ключевые слова: правопримененительная деятельность, юридическая (правовая) квалификаиия, логические основания юридической квалификации, правовая неопределенность, логический модус, лежаший в основе квалификации, алгоритм квалификации, формализация процесса принятия решения, эффективность и оперативность правосудия, логическая природа правовой нормы.

Научная специальность: 12.00.00 - юридические науки. 